\title{
Hvernig getum við bætt meðferð sjúklinga með brátt hjartadrep?
}

\section{Ingibjörg J.
Guðmundsdóttir \\ Ingibjörg J.
Guð̌mundsdóttir \\ yfirlæknir hjartapræðinga- \\ deildar Landspítala}

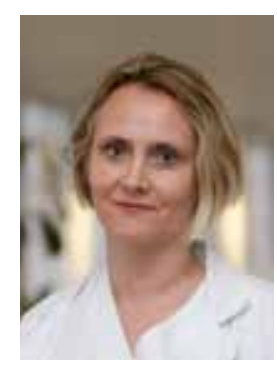

ig@landspitali.is

Brátt hjartadrep með ST-hækkunum (STEMI) er lífshættulegt ástand og mikilvægt að greina sjúkling og meðhöndla án tafar. Besta meðferð er tafarlaus víkkun á lokaðri kransæð (primary percutaneous coronary intervention, PPCI) en sú meðferð gagnast best ef æðin er opnuð innan tveggja til priggja klukkustunda frá fyrstu einkennum og pær aðgerðir eru gerðar á hjartapræðingadeild Landspítala við Hringbraut. Alpjóðlegar leiðbeiningar mæla með að kransæðavíkkun sé gerð innan 120 mínútna (helst innan 90 mínútna) frá fyrstu samskiptum við heilbrigðisstarfsmann (FSH) og innan 60 mínútna frá komu á PPCI-sjúkrahús, tafir í meðferð auka dánartíðni sjúklinga. ${ }^{1}$ Ef útlit er fyrir að ekki náist að opna æð sjúklings innan tveggja tíma, á að íhuga segaleysandi meðferð, einkum ef hægt er að gefa segaleysingu innan 6 tíma frá fyrstu einkennum. ${ }^{2}$ Hins vegar ætti gjöf segaleysingar ekki að tefja fyrir flutningi par sem einungis um helmingur sjúklinga fær fullnægjandi flæði eftir segaleysingu og allir sjúklingar fara einnig í hjartapræðingu.

Á strjálbýlu landi eins og Íslandi er nauðsynlegt að meta áhrif fjarlægða og flutningstíma á meðferð og koma auga á sóknarfæri til að minnka tafir á greiningu, lyfjagjöf og hjartainngripum. Раð er einnig mikilvægt að hafa í huga að á fámennum svæðum sér heilbrigðisstarfsfólk sjaldnar sjúklinga með hjartaáföll og verkferlar purfa að vera skýrir, pjálfun góð og sérfræðiráðgjöf auðfengin.

Í grein Póris Sigmundssonar og samstarfsmanna hans í Læknablaðinu er flutningstími allra landsbyggðarsjúklinga sem fengu STEMI á tveggja ára tímabili, 2011-2012, skoðaður, borinn saman eftir landshlutum og kannað hvort verkferlum hafi verið fylgt. Í ljós kom að pó að flestir sjúklingar hafi að endingu fengið góða meðferð voru tafir á meðferð hjá meirihluta sjúklinga. Sérstaklega kann að vera að flutningstími sjúklinga á suðursvæði hafi verið vanmetinn eða að ekki hafi verið aðgangur að segaleysandi meðferð, pví peirri meðferð var ekki beitt. Ekki er gerður samanburður við sjúklinga af höfuðborgarsvæðinu í greininni.

Ekki er síður mikilvægt að sjúklingar og almenningur séu vel upplýstir um viðbrögð við brjóstverkjum og einkennum um hjartaáfall par sem að jafnaði liðu um 80 mínútur frá fyrstu einkennum par til leitað var hjálpar. Jafnframt parf að skerpa á peim leiðbeiningum að gefa aspirín, annað blóðflöguhemlandi lyf (klópídógrel, prasugrel eða ticagrelor) og 5000 einingar af heparíni í æð og íhuga hvaða lyf er hægt að gefa í sjúkrabílum. Opnun bráđamóttöku hjartasjúklinga á Landspítala við Hringbraut (Hjartagáttar) myndi einnig spara mikilvægan tíma par sem viðkoma í Fossvogi tekur að sjálfsögðu tíma og virðist valda 25 mínútna töf samkvæmt greinarhöfundum.

Greinin sem er nú birt í Læknablaðinu vekur okkur til umhugsunar um umbætur og mikilvægt er að fylgja eftir og læra af pessari vinnu.

Tökum höndum saman, tafir í greiningu og meðferð geta skipt sköpum:
- Upplýsum sjúklinga: Ef pú færð verk eða pyngsli fyrir brjósti sem pú heldur að gæti verið hjartaáfall, stundum með leiðni í handlegg, kjálka eða bak og stundum með mæði, svita eða ógleði hringdu strax á sjúkrabíl og sestu svo niður eða leggstu uns aðstoð kemur, taktu hjartamagnýl ef pú hefur pað við höndina.

- Tölum saman: Ef sjúklingur er á landsbyggðinni er mikilvægt að láta vita að sjúklingur sé á leiðinni sem talinn er vera með kransæðastíflu, senda hjartalínurit og fá ráðleggingar um meðferð. Pá er hægt að kalla út hjartapræðingateymi tímanlega svo pað geti verið tilbúið.

- Skoðum verkferla: Ætti að gefa önnur lyf en hjartamagnýl í sjúkrabílum og hvar er hægt að gefa segaleysandi meðferð? Er mögulegt að beina sjúklingum beint á Landspítala við Hringbraut alla daga ársins?

\section{Heimildir}

1. PG Steg, SK James, D Atar, for the Task Force on the management of ST-segment elevation acute myocardial infarction of the European Society of Cardiology (ESC), et al. ESC Guidelines for the management of acute myocardial infarction in patients presenting with ST-segment elevation. Eur Heart J 2012; 33: 2569-619.

2. Gershlick AH, Banning AP, Myat A, Verheugt FW, Gersh BJ. Reperfusion therapyfor STEMI: is there still a role for thrombolysis in the era of primary percutaneouscoronary intervention? Lancet 2013; 382: 624-32.

3. bhf.org.uk/heart-health/conditions/heart-attack - desember 2015

Management of STEMI patients from rural areas in Iceland - Is there room for improvement?

Ingibjörg Jóna Guðrmundsdóttir Cand Med, MRCP, Dr Med. Interventional Cardiologist and Director of Cardiac Interventions, University Hospital Iceland 